QUALITY

Volume 5, Nomor 1, 2017: 83-103

\title{
MENINGKATKAN KUALITAS KARYA ILMIAH MAHASISWA MELALUI BIMBINGAN SELF REGULATED LEARNING
}

\author{
Eva Latipah \\ UIN Sunan Kalijaga Yogyakarta \\ evalatipah@yahoo.co.id
}

\begin{abstract}
Abstrak
Penelitian ini dilakukan untuk merancang model bimbingan regulasi diri dalam belajar dan menguji efektivitas model tersebut dalam meningkatkan kualitas karya ilmiah mahasiswa. Perancangan model dilakukan dengan mengidentifikasi kebutuhan mahasiswa dan menerapkan model dalam proses bimbingan karya ilmiah mahasiswa. Subjek dalam penelitian ini mahasiswa yang sedang menyusun skripsi/tesis berjumlah 42 orang di lingkungan UIN Sunan Kalijaga Yogyakarta. Hasil identifikasi kebutuhan menunjukkan bahwa mahasiswa membutuhkan bimbingan tentang strategi untuk menyelesaikan skripsi/tesis dengan cepat dan tepat. Dengan menerapkan model bimbingan tersebut kualitas skripsi/tesis mahasiswa meningkat secara signifikan yang ditunjukkan dalam nilai skripsi/tesis yang diperoleh.
\end{abstract}

Kata Kunci: Model Bimbingan, Belajar Berdasar Regulasi diri dan kualitas karya ilmiah

\begin{abstract}
This study was conducted to design a guidance model of self regulated learning and test effectiveness of this model in improving quality of students scientific work. Design of model is done by identifying needs of students and apply model in guidance process of students scientific work. Subjects in this study are student who is writing their thesis numbered 42 people in UIN Sunan KAlijaga Yogyakarta. The results show that students need guidance on a strategy to complete thesis quickly and precisely. By applying that guidance model quality of students thesis increased significantly shown in value of thesis that be obtained.
\end{abstract}

Keywords: Guidance Model, Self Regulated Learning, Quality of Work Scientific

\section{A. Pendahuluan}

Menulis karya ilmiah merupakan sebuah keniscayaan bagi mahasiswa sebagai penunjang studinya. Karya ilmiah dapat berbentuk makalah, laporan praktikum, skripsi (tugas akhir), tesis, dan disertasi (Arikunto, 2010). Skripsi dijadikan sebagai salah satu syarat kelulusan di program S-1 dengan maksud memberikan kesempatan kepada mahasiswa untuk menunjukkan bahwa dia dapat 


\section{QUALITY}

Volume 5, Nomor 1, 2017: 83-103

menerapkan langkah-langkah pendekatan ilmiah untuk memperoleh pengetahuan dan melaporkannya secara tertulis (Latipah, 2014).

Berbeda dengan skripsi, tesis dijadikan syarat kelulusan di program S-2 dengan maksud memberikan kesempatan kepada mahasiswa untuk menunjukkan bahwa dia dapat membuat suatu sintesis baru atau penerapan pengetahuan yang sudah ada, dan melaporkannya secara tertulis. Sementara disertasi dijadikan syarat kelulusan di program S-3 dengan maksud memberikan kesempatan kepada mahasiswa untuk menunjukkan bahwa dia memahami (mengikuti) perkembangan mutakhir pengetahuan ilmiah di bidang ilmunya dan memberikan sumbangan pada perkembangan ilmu itu melalui penemuan baru yang orisinal yang dilaporkannya secara tertulis (Agung Wahyudi Biantoro, 2009, dalam https://uripsantoso.wordpress.com/2012/04/12/perbedaan-skripsi-tesis-dandisertasi-secara-sederhana/ diunduh tanggal 16 Pebruari 2015, pukul 9:25).

Penulisan skripsi merupakan ajang latihan bagi mahasiswa untuk melakukan penelitian secara objektif. Atas hal tersebut, mahasiswa S1 sangat membutuhkan bimbingan dosen agar tidak melakukan kesalahan fatal yang menyebabkan mereka harus mengulang. Bimbingan dosen dalam penyusunan skripsi memiliki porsi cukup besar (yaitu sekitar 40\%) jika dibandingkan dengan peran dosen dalam membimbing tesis (sekitar 20\%) dan disertasi (sekitar 10\%). Tesis merupakan ajang peningkatan kemampuan mahasiswa dalam meneliti dan diharapkan mahasiswa sudah mampu meneliti dengan bimbingan yang minimal dari dosen. Demikian juga dengan disertasi merupakan pembuktian kemampuan mahasiswa S3 dalam meneliti secara mandiri. Secara sederhana, skripsi menjawab tentang apa, tesis menjawab tentang apa dan mengapa, dan disertasi menjawab tentang apa, mengapa, dan bagaimana (Biantoro, 2009).

Sejumlah mahasiswa melaporkan bahwa yang menyebabkan mereka terlambat dalam penyusunan skripsi dikarenakan beberapa hal seperti: ketidakmampuannya untuk mengungkapkan keinginannya tentang hal yang akan diteliti, judul skripsi yang diajukan selalu mendapat penolakan dari pejabat yang berwenang, bingung karena tidak ada teman seangkatan tempat berbagi (share) ketika mengalami kesulitan, dan ketidaksesuaian waktu bimbingan antara dirinya 


\section{QUALITY}

Volume 5, Nomor 1, 2017: 83-103

dengan dosen penasehat akademik (yang sering mereka istilahkan sebagai 'sulit bertemu dosen pembimbing') (Latipah, 2015).

Bimbingan dari dosen terhadap penyusunan skripsi sangatlah penting. Bahkan untuk level S1 bimbingan dosen mencapai 40\%. Atas hal ini dapat dipahami bahwa dosen pembimbing turut berpengaruh terhadap kesuksesan mahasiswa dalam penyusunan skripsi. Meskipun demikian, kemandirian mahasiswa merupakan hal yang utama. Dalam penyusunan skripsi kemandirian mahasiswa mencapai 60\%. Ini artinya kemandirian mahasiswa lebih besar pengaruhnya terhadap kesuksesan mereka dalam penyusunan skripsi. Atas hal tersebut, dalam memberikan bimbingan, dosen perlu mengarahkan bagaimana caranya agar mahasiswa mencapai kemandirian dalam menyusun skripsi. Dalam hal ini dosen perlu merancang model bimbingan menuju pada kemandirian dalam belajar mahasiswa. Dalam istilah psikologi, konsep yang memperkenalkan tentang kemandirian dalam belajar, termasuk kemandirian dalam melakukan penelitian, dikenal sebagai istilah regulasi diri dalam belajar (self regulated learning) (Pekrun, dkk., 2002; Ainley \& Patrick, 2006; Saddler, 2006).

Self regulated learning merupakan belajar dengan cara mengaktifkan motivasi diri, metakognisi, dan evaluasi diri. Dalam konteks bimbingan, bimbingan berbasis self regulated learning adalah bimbingan dengan cara membangkitkan motivasi mahasiswa dalam belajar; memberikan pengarahan bagaimana menggunakan strategi-strategi secara fleksibel, seperti kapan pengambilan data sebaiknya dilakukan. Pengambilan data melibatkan banyak pihak, karenanya peneliti perlu memiliki strategi yang tepat untuk hal ini; mengarahkan mahasiswa dalam membuat perencanaan-perencanaan untuk mencapai target yang akan dicapai, seperti target wisuda kapan, dengan target tertentu, mahasiswa perlu memiliki perencanaan yang baik terkait penyusunan skripsinya; dan memberi pandangan tentang apa yang harus dilakukan mahasiswa jika mereka mengalami kesulitan terkait keterbatasan pengetahuan yang dimilikinya, apakah mengandalkan belajar otodidak saja atau perlu bertanya kepada teman yang lebih ahli, dan seterusnya (Zimmerman, 1998). 


\section{QUALITY}

Volume 5, Nomor 1, 2017: 83-103

Regulasi diri dalam belajar terbukti mampu meningkatkan prestasi akademik. Penelitian Latipah (2010) dengan menggunakan kajian meta analisis ditemukan bahwa terdapat korelasi yang sangat signifikan antara strategi belajar berdasar regulasi diri dengan prestasi belajar. Korelasi popluasi yang sesungguhnya setelah dikoreksi oleh kesalahan pengukuran diestimasikan sebesar 0,339 , varians populasi 0,111 , dan standar deviasi 0,333 ; dan dengan mengacu pada interval kepercayaan 95\% dengan batas penerimaan antara $-0,313<\varrho<$ 0,991, maka nilai korelasi dinyatakan masuk dalam batas interval. Adapun korelasi populasi setelah dikoreksi dengan jumlah sampel adalah sebesar 0,272, varians korelasinya 0,075, standar deviasi 0,333; dan dengan mengacu pada interval kepercayaan 95\% dengan batas penerimaan antara $-0,342<\varrho<0,732$, maka nilai korelasi dinyatakan masuk dalam batas interval.

Penelitian Man-Chih (2006) menunjukkan bahwa regulasi diri dalam belajar mampu meningkatkan kepuasan mahasiswa dalam bidang olah raga. ManChih melibatkan satu kelompok eksperimen dan satu kelompok kontrol. Kelompok eksperimen diberi perlakuan berupa penerapan strategi belajar berdasar regulasi diri, sementara kelompok kontrol tidak diberi apa-apa alias menggunakan strategi pembelajaran olah raga biasa. Selama sesi eksperimen mereka dipantau kegiatannya, dan diakhir sesi pembelajaran kedua kelompok diminta untuk menyampaikan terkait persepsi mereka tentang pengalaman belajarnya. Hasilnya menunjukkan bahwa pada kelompok eksperimen menyatakan bahwa mereka merasa puas dengan pembelajaran yang telah dilakukan (yaitu pembelajaran dengan menerapkan strategi belajar berdasar regulasi diri). Karena merasa puas, prestasi mereka dalam bidang tennis-pun meningkat. Dengan kata lain, mereka merasa puas dengan dua hal yakni dengan pembelajarannya itu sendiri dan dengan keterampilan yang diperolehnya dalam bidang tennis. Ini selaras dengan temuan kuantitatif yang telah dianalisis yang menunjukkan korelasi tinggi dan sangat signifikan $(r=0,72 ; p=0,000)$. Selanjutnya penelitian ini bertujuan merancang model bimbingan 'regulasi diri dalam belajar' dan mengetahui efektivitas model tersebut dalam meningkatkan kualitas skripsi/tesis mahasiswa. 


\section{QUALITY}

Volume 5, Nomor 1, 2017: 83-103

Penelitian ini merupakan penelitian research and development, yaitu penelitian yang dilakukan untuk menghasilkan sebuah produk yang akan digunakan dalam dunia pendidikan melalui proses yang ilmiah yang diakhiri dengan tahapan validasi (Latipah, 2014). Subjek dalam penelitian ini adalah para mahasiswa Fakultas Ilmu Tarbiyah dan Keguruan UIN Sunan Kalijaga yang sedang menyelesaikan tugas akhirnya (skripsi/tesis) dan dibimbing oleh peneliti pada tahun akademik 2015/2016 sebanyak 38 orang mahasiswa. Ada dua instrumen yang digunakan dalam pengumpulan data ini yaitu modul bimbingan regulasi diri dalam belajar dan pedoman penilaian kualitas skripsi.

\section{B. Pembahasan}

\section{Model Bimbingan Regulasi Diri dalam Belajar}

\section{a. Identifikasi Kebutuhan}

Identifikasi kebutuhan dilakukan untuk mengetahui kebutuhan mahasiswa dalam proses bimbingan skripsi/tesis. Ini dilakukan dengan cara menyebar angket kepada mahasiswa yang dibimbing skripsi/tesisnya oleh peneliti. Proses identifikasi berlangsung selama 2 minggu, tepatnya pada tanggal 5 sampai dengan 18 Juni 2016.

Hasil identifikasi diperoleh yang disimpulkan dalam poin-poin berikut: 1 . Mahasiswa menghendaki agar dosen memberi jadwal yang jelas untuk bimbingan, 2. Dosen memberikan semangat agar mahasiswa segera lulus dalam menyelesaikan skripsi, 3. Dosen mengarahkan tentang strategi-strategi atau caracara jitu dalam menggarap skripsi, 4. Dosen memberi solusi jika mahasiswa melakukan kekeliruan (tidak hanya menyalahkan) dalam menyusun skripsi, 5. Dosen memberi keleluasaan kepada mahasiswa terkait teori dan cara meneliti. Selanjutnya hasil identifikasi tersebut dijadikan acuan dalam penyusunan modul bimbingan regulasi diri dalam belajar.

\section{b. Penyusunan Modul Bimbingan Regulasi Diri dalam Belajar}

Berdasar hasil identifikasi, dilakukan diskusi (Focus Group Discussion) dengan tim ahli (psikologi dan pendidikan) untuk merancang materi modul bimbingan regulasi diri dalam belajar. Hasil FGD selanjutnya dituangkan dalam 


\section{QUALITY}

uraian modul bimbingan regulasi diri dalam belajar. Adapun Isi modul berdasar hasil FGD meliputi:

1) Cara peningkatan motivasi menyusun skripsi/tesis. Ini dilakukan dengan cara-cara sebagai berikut.

a) Mendeskripsikan arti penting (kebermaknaan) skripsi/tesis bagi mereka. Pada bagian ini subjek diminta untuk menguraikan kebermaknaan skripsi/tesis sesuai dengan yang dirasakan baik yang bersumber dari diri sendiri, orang tua, saudara, teman, kampus, atau yang lainnya.

b) Meningkatkan atribusi diri. Ini dilakukan dengan cara subjek diminta mengidentifikasi faktor-faktor yang menjadi penyebab keberhasilan dan kegagalan dalam menyusun skripsi/tesis.

c) Meningkatkan efikasi diri. Pada bagian ini subjek diminta mengidentifikasi dan memberikan skor atas tingkat efikasi dirinya pada bagian dari skripsi/tesis yang sedang disusunnya.

d) Mengembangkan tujuan belajar. Pembahasan tujuan belajar mencakup tiga aspek yaitu arah tujuan belajar, isi tujuan belajar, dan komitmen terhadap tujuan. Pada bagian ini subjek diminta untuk mengisi tentang tujuan belajarnya berdasar tiga aspek tersebut.

2) Terampil menggunakan strategi menyusun skripsi/tesis meliputi bagaimana memahami materi bahan skripsi/tesis, bagaimana cara membaca materi bahan skripsi/tesis, bagaimana mencatat dan mengikuti bimbingan, bagaimana mengorganisasi atau menyusun materi bahan skripsi/tesis, bagaimana cara menghadapi ujian skripsi/tesis, dan bagaimana menyusun jadwal untuk diri sendiri.

\section{c. Validasi Modul (FGD)}

Setelah tersusun poin-poin modul bimbingan regulasi diri dalam belajar dengan mengacu pada hasil identifikasi kebutuhan, poin-poin tersebut didiskusikan bersama tim ahli terkait yakni ahli bidang psikologi dan ahli bidang pendidikan. Diskusi berlangsung dalam kegiatan bernama FGD (Focus Group Discussion). Dalam kegiatan ini dilakukan diskusi dengan memokuskan pada hal 


\section{QUALITY}

Volume 5, Nomor 1, 2017: 83-103

yang utama yakni merumuskan poin-poin bimbingan yang idealnya diberikan kepada mahasiswa yang sedang dibimbing skripsi/tesisnya.

Hasil FGD diperoleh bahwa selain poin-poin yang sudah dirumuskan, dalam bimbingan skripsi/tesis, mahasiswa perlu diberikan contoh konkrit perihal model skripsi/tesis yang diinginkan. Misal jika penelitiannya berjenis kuantitatif, mahasiswa perlu diberikan contoh model penelitian kuantitatif. Jika penelitiannya berjenis kualitatif, perlu diberikan contoh model penelitian kualitatif. Dengan demikian akan memudahkan pembimbing atau bahkan penguji dalam proses penilaiannya.

\section{d. Deskripsi Subjek Penelitian}

Penggolongan data yang dilakukan terhadap subjek penelitian meliputi jenjang pendidikan yaitu S1 atau S2. Ini merupakan variabel yang dikontrol sehingga dengan sendirinya seluruh subjek memiliki jenjang pendidikan yang relatif sama yaitu S-1 dan S-2 UIN Sunan Kalijaga Yogyakarta. Selanjutnya dapat dilihat dari Tabel 1.

Tabel 1. Deskripsi Subjek Penelitian

\begin{tabular}{|c|c|c|c|}
\hline No. & Jenjang & Jumlah (orang) & Presentase (\%) \\
\hline 1. & Sarjana (S1) & 25 & 60 \\
\hline 2. & Magister (S2) & 17 & 40 \\
\hline & Jumlah & 42 & 100 \\
\hline
\end{tabular}

Keseluruhan subjek berdasar data di atas berjumlah 42 orang. Mereka terdiri atas 25 mahasiswa Program Sarjana (S1), dan 17 mahasiswa program magister (S2).

\section{e. Pelaksanaan Bimbingan Regulasi Diri dalam Belajar}

Bimbingan regulasi diri dalam belajar dilaksanakan selama satu semester yakni semester Genap Tahun Akademik 2015/2016. Seluruh mahasiswa bimbingan yang menjadi subjek dalam penelitian ini dikumpulkan untuk mendapatkan briefing terlebih dahulu perihal pelaksanaan bimbingan. Dalam briefing disampaikan bahwa bimbingan dilaksanakan secara rutin pada setiap hari senin jam 10.00 sampai 12.00; selasa jam 08.00-10.00; dan rabu jam 14.00 sampai 16.00 . 


\section{QUALITY}

Volume 5, Nomor 1, 2017: 83-103

Dengan alokasi waktu seperti itu, mahasiswa diberi jatah bimbingan satu kali dalam dua minggu. Dengan kata lain mahasiswa bimbingan dua minggu sekali, tidak seminggu sekali. Dengan demikian 42 orang mahasiswa dibagi 6 (selama dua minggu), diperoleh hasil 7 orang. Ini artinya dalam satu pertemuan ada 7 orang yang bimbingan. Jika waktu yang tersedia untuk satu kali bimbingan adalah 120 menit (dua jam), maka jatah mahasiswa untuk bimbingan adalah 120 menit dibagi 7 orang, diperoleh hasil 17 menit. Dengan demikian mahasiswa mendapat jatah waktu untuk satu kali bimbingan selama kurang lebih 17 menit. Namun ini fleksibel menyesuaikan dengan kebutuhan mahasiswa. Terkadang ada bimbingan hanya untuk konfirmasi teori yang akan digunakan, atau minta tanda tangan saja. Untuk jenis bimbingan seperti ini tentunya tidak menggunakan waktu yang banyak, sehingga bisa digunakan oleh mahasiswa lain yang memerlukan waktu lebih banyak dalam bimbingan.

Siklus di atas dilakukan selama satu semester. Setelah satu semester, mahasiswa diminta untuk mengisi form bimbingan regulasi diri dalam belajar, kemudian dinilai skripsinya. Nilai skripsi bukan berdasar nilai ujian skripsi melainkan berdasar penilaian tim yang terlibat dalam penyusunan modul regulasi diri dalam belajar, dengan asumsi bahwa mereka mempunyai persepsi yang sama tentang kualitas yang dimaksud.

\section{f. Kualitas Skripsi/Tesis Mahasiswa}

Dari skripsi/tesis yang sudah dibimbing secara intensif dengan menerapkan model bimbingan regulasi diri dalam belajar selama satu semester, langkah selanjutnya adalah menilai kualitas skripsi/tesis. Penilaian dilakukan dengan melibatkan tim sebagaimana tim yang terlibat dalam penyusunan modul bimbingan regulasi diri dalam belajar. Dari hasil penilaian, berikut disampaikan hasilnya.

\section{1) Penyusunan Judul Skripsi/Tesis}

Dari segi judul, 98\% (41 orang) dinilai sudah bagus. Ini didasarkan pada kelugasan judul yakni efektif dan efisien. Dikatakan efektif karena judul diuraikan dengan benar dan tepat sesuai dengan jenis penelitiannya. Misalnya, jika penelitiannya eksperimen, maka judulnya menggunakan kata pengaruh atau 


\section{QUALITY}

Volume 5, Nomor 1, 2017: 83-103

efektivitas. Jika penelitiannya lapangan dan ingin melihat keterkaitan antara variabel $\mathrm{X}$ dan $\mathrm{Y}$ maka judul penelitiannya menggunakan kata 'hubungan antara $\mathrm{X}$ dan $\mathrm{Y}^{\prime}$. Dikatakan efisien karena judul-judul diuraikan dengan seharusnya. Misalnya, pengaruh X terhadap $\mathrm{Y}$, bukan pengaruh $\mathrm{X}$ dengan $\mathrm{Y}$ atau Pengaruh $\mathrm{X}$ dan $\mathrm{Y}$. Contoh lainnya, hubungan $\mathrm{X}$ dan $\mathrm{Y}$, bukan hubungan $\mathrm{X}$ terhadap $\mathrm{Y}$. Dengan demikian hanya ada satu orang saja yang dinyatakan belum membuat judul secara efektif dan efisien.

Penelitian berjenis kuantitatif kebanyakan diawali dengan kata 'hubungan, perbedaan, pengaruh, dan efektivitas'. Penelitian berjenis kualitatif kebanyakan menggunakan kata 'model, penerapan, dampak, faktor-faktor yang mempengaruhi', dan seterusnya.

Masih adanya mahasiswa yang merumuskan judul penelitian tidak secara lugas disebabkan mahasiswa tersebut memiliki pendirian kukuh bahwa judul penelitiannya yang diinginkannya, seperti itu. Dengan kata lain, pembimbing sudah memberikan masukan bagaimana merumuskan judul yang ideal namun karena kekukuhan mahasiswa pembimbingpun memberikan keleluasaan kepada mahasiswa untuk merumuskan judul sebagaimana keinginannya. Namun dalam proses penilaian, tim peneliti tetap mengacu pada pedoman penilaian yang telah disusun.

2) Penyusunan Latar Belakang Masalah

Latar belakang masalah berisi uraian tentang pentingnya masalah (variabel dependen) diteliti. Dikatakan juga bahwa dalam latar belakang masalah diuraikan tentang adanya perbedaan antara teori dan praktek (dasolen dan dasein). Tentang pentingnya masalah diteliti dapat menggunakan berbagai perspektif seperti pendidikan, psikologi, agama, sosiologi, dan seterusnya.

Berdasar hasil penilaian diperoleh hasil bahwa hanya 60\% (25 dari 42 orang) saja yang berhasil menguraikan latar belakang masalahnya dengan benar. Dari 25 tersebut kebanyakan (75\%, 19 orang) adalah karya ilmiah berjenis skripsi, bukan tesis. Hal ini disebabkan salah satunya oleh porsi kemandirian yang diberikan pembimbing untuk mahasiswa jenjang S2 lebih besar dibandingkan untuk mahasiswa jenjang S1 sebagaimana idealnya (semakin tinggi jenjang 


\section{QUALITY}

Volume 5, Nomor 1, 2017: 83-103

pendidikan semakin tinggi kemandirian yang dituntut). Atas porsi kemandirian tersebut menyebabkan mahasiswa berkreasi secara leluasa dan terkadang kurang jelas alurnya, sehingga hal-hal penting yang harus muncul dalam latar belakang masalah, malah kurang atau tidak ada.

Uraian latar belakang masalah yang benar mencakup pentingnya masalah diteliti. Sejumlah mahasiswa mengambil alasan berspektif psikologi. Ketika mahasiswa ditanya mengapa demikian. Mereka mengungkapkan bahwa bukubuku referensinya lebih banyak daripada buku-buku pendidikan. Tentu saja ini sesuatu yang menggembirakan karena menurut pantauan peneliti justru buku-buku psikologi masih minim. Jika demikian maka ini bisa saja mengindikasikan bahwa sarjana bidang psikologi semakin banyak khususnya banyak yang berkarya dengan menuangkan tulisannya.

Di sisi lain mereka cukup kesulitan ketika mencari alasan dengan perspektif ilmu agama. Alasan mereka bahwa buku-buku agama lebih minim daripada buku psikologi, dan kalaupun ada seringkali masih dalam bahasa Arab (kitab-kitab). Tentu saja ini tantangan bagi ahli dalam bidang agama untuk menerjemahkan buku-buku berbahasa arab ke dalam bahasa Indonesia agar ilmu agama dapat ter-share ke khalayak secara baik.

Tidak hanya alasan pentingnya masalah diteliti, dalam latar belakang masalah perlu diperkuat dengan fakta di lapangan (fakta empiris) terutama fakta di lokasi yang akan diteliti. Hasil yang diperoleh terhadap penilaian skripsi/tesis, mahasiswa masih cukup kesulitan bagaimana menarasikan bukti di lapangan. Mereka masih banyak yang beranggapan bahwa bukti empiris tersebut dilaporkan dalam hasil. Padahal, berbeda antara hasil observasi awal dengan hasil observasi ketika pengumpulan data. Hasil observasi awal disebut sebagai pre liminary dan itu disajikan pada bagian latar belakang masalah. Adapun hasil observasi dalam rangka pengumpulan data disajikan pada bagian hasil penelitian. Ketika peneliti bertanya mengapa hasil observasi awal tidak disampaikan dalam latar belakang masalah, kebanyakan dari mereka mengatakan bahwa itu disajikan dalam hasil.

Lemahnya mahasiswa dalam menampilkan bukti-bukti pendukung dalam latar belakang masalah menyebabkan latar belakang masalah mereka nampak 


\section{QUALITY}

Volume 5, Nomor 1, 2017: 83-103

sebagai common sense yakni sesuatu yang menjadi anggapan kuat namun belum dibuktikan secara ilmiah. Mereka perlu menjadikan informasi-informasi yang diperolehnya di lapangan disertai dengan bukti-bukti yang ada sehingga hal itu menjadi sebuah science (ilmu pengetahuan).

3) Penyusunan Rumusan Masalah

Hasil penilaian terhadap skripsi/tesis ditemukan bahwa 85\% (36 dari 42 orang) merumuskan masalahnya dengan benar. Penelitian berjenis korelasi kebanyakan merumuskan masalahnya menjadi 4 seperti berikut: seberapa tinggi prestasi belajar PAI, seberapa tinggi IQ subjek, apakah ada hubungan antara IQ dan prestasi belajar PAI, berapa besar kontribusi IQ terhadap prestasi belajar PAI. Penelitian berjenis eksperimen merumuskan masalahnya hampir sama dengan jenis korelasi, hanya saja pada bagian pertanyaan apakah ada hubungan diganti dengan apakah $\mathrm{X}$ berpengaruh terhadap $\mathrm{Y}$.

Untuk penelitian berjenis kualitatif, kebanyakan masih bersifat deskriptif teruama penelitian skripsi, sementara penelitian tesis sudah ada yang tidak hanya penelitian deskriptif yakni sudah menggunakan data verbatim. Ketika ditanya mengapa mahasiswa yang menyusun skripsi tidak menggunakan data verbatim, kebanyakan dari mereka (90\%) menjawab bahwa itu masih sulit bagi mereka. Maksud sulit di sini adalah sulit dalam mengolah data verbatimnya dan sulit dalam menganalisis kata-katanya.

\section{4) Penyusunan Tujuan Penelitian}

Penyusunan tujuan penelitian sangat bergantung pada rumusan masalah. Jika rumusan masalah ada empat maka tujuan penelitianpun ada empat. Perbedaannya adalah bahwa jika rumusan masalah berbentuk pertanyaan, maka tujuan penelitian berbentuk pernyataan. Namun demikian seringkali pada bagian ini mahasiswa melakukan kesalahan yakni merumuskan tujuan penelitian dalam bentuk pertanyaan -karena mereka menyusun tujuan penelitian dengan cara kopi paste dari rumusan masalah. Termasuk dalam penelitian ini, masih ada sekitar 15\% (6 dari 42 orang) yang melakukan kesalahan berupa penyusunan tujuan penelitian dalam bentuk pertanyaan. Ketika dikonfirmasi kepada mereka, 


\section{QUALITY}

Volume 5, Nomor 1, 2017: 83-103

mahasiswa menjawabnya bahwa itu merupakan kekhilafan mereka karena mereka melakukannya dengan cara kopi paste (seperti yang diduga peneliti).

5) Penyusunan Manfaat Penelitian

Pada bagian ini manfaat dibagi dua yakni manfaat teorwtis dan praktis. Manfaat teoretis ditujukan bagi keilmuan yang sedang digeluti dan manfaat praktis disesuaikan dengan subjek penelitiannya. Manfaat penelitian ditujukan yang utama kepada subjek penelitian. Setelah itu bisa ditujukan kepada pihakpihak terkait. Misalnya judul penelitiannya Pengaruh Metode Synergetic Teaching terhadap Kemampuan Berempati Siswa. Berdasar judul penelitian ini yang menjadi subjeknya adalah siswa, maka manfaat utama penelitiannya harus ditujukan kepada atau untuk siswa. Setelah siswa, peneliti boleh menyampaikan manfaat penelitian untuk guru dan kepala sekolah sebagai pengambil kebijakan.

Hasil penilaian terhadap skripsi/tesis, 88\% (37 dari 42 orang) sudah berhasil dengan baik dalam menyusun manfaat penelitiannya. Sisanya, 12\% (5 dari 42 orang) dinilai belum benar dalam menyusun manfaat penelitian terutama dalam menyusun manfaat praktis. Masih ada yang menyusun manfaat praktis tapi masuk pada manfaat teoretis (terbalik). Ketika ditanyakan mengapa hal itu terjadi kepada subjek, mereka menjawab bahwa mereka belum paham tentang manfaat teoretis dan praktis yang dimaksud.

6) Penyusunan Kajian Pustaka

Kajian pustaka merupakan upaya seorang peneliti untuk melakukan pengkajian atas masalah atau variabel yang diteliti untuk menyatakan apakah penelitiannya sudah pernah dilakukan orang lain atau belum. Ini dilakukan dengan cara menelusuri karya-karya ilmiah seperti artikel, skripsi, tesis, atau bahkan disertasi. Dari karya-karya ilmiah tersebut seorang peneliti mencari persamaan atau perbedaannya lalu disimpulkan. Dari 42 orang subjek penelitian, semua subjek (100\%) sudah melakukan kajian pustaka dengan benar.

Ada perbedaan jumlah karya ilmiah yang harus dikaji oleh para mahasiswa sebagai subjek penelitian. Untuk skripsi, diminta minimal 6 karya ilmiah yang harus dicantumkan dalam skripsi, sementara untuk tesis minmal harus mencantumkan 12 karya ilmiah. Dengan acuan yang jelas ini membuat subjek 


\section{QUALITY}

Volume 5, Nomor 1, 2017: 83-103

mematuhinya sehingga seperti yang disampaikan, semua subjek sudah melakukan kajian pustaka dengan benar.

7) Penyusunan Landasan Teori

Berbeda dengan kajian pustaka, penyusunan landasan teori merupakan upaya peneliti merancang teori dari variabel yang ditelitinya. Perancangan teori setidaknya perlu memuat poin-poin: definisi, aspek-aspek, dan faktor-faktor yang mempengaruhi. Definisi digunakan untuk memberi batasan yang jelas tentang maksud dari variabel yang ditelitinya. Aspek-aspek disusun untuk merancang instrumen penelitian, karena dari aspek-aspek inilah seorang peneliti bisa menjabarkan indikator-indikator dari variabel yang ditelitinya. Faktor-faktor yang mempengaruhi perlu dimunculkan untuk memahami kesalingterkaitan antar variabel yang diteliti.

Dalam penyusunan landasan teori kebanyakan subjek masih nampak 'kalang kabut'. Ini artinya belum semuanya memahami bagaimana cara menyusun landasan teori sehingga hanya 56\% (23 dari 42 orang) yang menyusun landasan teori sesuai dengan seharusnya (idealnya). Dari 23 orang tersebut kebanyakan dari mahasiswa program magister (S2) yakni mencapai 72\% (16 dari 23 orang). Hal ini bisa jadi dikarenakan referensi yang digunakan mahasiswa S2 lebih banyak yang tersedia di perpustakaan (perpustakaan pusat dan pasca) dibandingkan mahasiswa S1 yang hanya mendapatkan referensi di perpustakaan pusat saja (tidak ada perpustakaan khusus S1).

Selain ketersediaan referensi, lebih banyaknya mahasiswa S2 yang lebih baik dalam penyusunan landasan teori bisa disebabkan oleh faktor porsi kemandirian yang diberikan kepada mereka. Ini artinya bahwa mahasiswa S2 memiliki porsi kemandirian yang lebih besar dibandingkan dengan mahasiswa S1. Ini secara tidak langsung berdampak terhadap pola berpikir mereka yang lebih bebas, lebih leluasa, dan lebih kreatif dalam menyusun landasan teori.

8) Penyusunan Variabel Penelitian

Ada dua hal yang dilakukan pada bagian ini yakni mengidentifikasi variabel penelitian dan membuat definisi operasional dari setiap variabel penelitiannya. Pada bagian identifikasi variabel penelitian, semua subjek 


\section{QUALITY}

Volume 5, Nomor 1, 2017: 83-103

penelitian sudah mampu melakukannya dengan baik (100\%, 42 orang). Hal ini bisa jadi dikarenakan bagian identifikasi variabel penelitian merupakan hal yang teknis, artinya peneliti hanya menyebutkan variabel-variabel apa saja yang ditelitinya sehingga subjek merasa mudah.

Pada bagian definisi operasional variabel penelitian kebanyakan subjek melakukannya belum sebagaimana seharusnya (hanya 63\%, 26 dari 42 orang). Pada bagian ini subjek seharusnya menyampaikan pengertian variabel penelitian dengan batasan-batasan yang jelas. Misalnya, merumuskan definisi operasional dari 'prestasi belajar PAI'. Pengertian prestasi belajar sangat luas, banyak ahli yang berpendapat. Nah pada bagian ini subjek harus merumuskan secara tepat tentang apa itu prestasi belajar PAI, tidak sekedar prestasi belajar secara umum, dan bagaimana mengukurnya apakah berdasar raport, ulangan harian, ujian tengah semester atau ujian akhir semester, dan seterusnya.

Rendahnya subjek dalam merumuskan definisi operasional variabel penelitian bisa disebabkan oleh banyak faktor seperti ketidakpahaman terhadap definisi operasional itu sendiri, atau ketidakpahaman dalam membuat landasan teori dari variabel yang diteliti. Jika permasalahannya seperti ini, maka hal yang bisa dilakukan adalah memahamkan terlebih dahulu tentang apa itu definisi operasional variabel penelitian dan bagaimana cara menyusun landasan teori yang benar.

\section{9) Penentuan Subjek Penelitian}

Dalam menentukan subjek penelitian, 76\% (32 dari 42 orang) mahasiswa sebagai subjek penelitian sudah melakukannya dengan benar. Ini artinya bahwa sisanya $(24 \%, 10$ orang) belum bisa menentukan subjek penelitian secara benar. Mahasiswa yang mampu menentukan subjek penelitian secara benar dikarenakan mereka paham bagaimana cara menentukan subjek penelitian yaitu bahwa mereka harus memahami populasi dari penelitian mereka. Mahasiswa harus menentukan ciri-ciri yang jelas dari subjek yang menjadi populasi penelitiannya. Setelah menentukan ciri-ciri yang jelas dari populasi penelitiannya, mahasiswa baru menentukan apakah dia akan menjadi populasinya secara keseluruhan sebagai subjek penelitian atau tidak. Jika tidak, misal karena dipandang terlalu banyak, 


\section{QUALITY}

Volume 5, Nomor 1, 2017: 83-103

maka mahasiswa harus menggunakan sampel sebagai bagian dari populasinya. Dengan pemahaman yang baik tentang populasi dan sampel penelitian, mahasiswa dapat merumuskan subjek penelitian secara benar.

10) Penyusunan Instrumen Penelitian

Instrumen penelitian merupakan alat-alat yang digunakan untuk mengungkap variabel-variabel yang diteliti. Di sini mahasiswa perlu menentukan instrumen secara benar. Karena jika instrumennya salah maka hasil yang diperoleh akan bias. Permisalan, variabel yang diteliti adalah prestasi belajar PAI, maka instrumen yang digunakan adalah soal-soal PAI untuk mengungkap prestasi belajar PAI.

Dari 42 orang subjek, hanya $85 \%$ (35 dari 42 orang) yang mampu merumuskan instrumen penelitiannya secara tepat, dan kebanyakan dimiliki oleh mahasiswa S2. Sisanya (15\%, 7 orang) dipandang belum tepat dalam menentukan instrumen penelitian. Subjek yang tepat menentukan instrumen penelitian dikarenakan beberapa faktor diantaranya adalah karena mereka memahami dengan baik tentang instrumen dan jenis-jenis instrumen penelitian. Mereka yang masih salah dalam menentukan instrumen penelitian dikarenakan bingung, instrumen apa yang harus digunakan. Akhirnya mereka mencantumkan seadanya, sebagaimana mereka ketahui.

Penentuan instrumen yang benar banyak terjadi pada mahasiswa S2 dikarenakan mereka sudah punya pengalaman lebih banyak. Seperti hasil wawancara bahwa kebanyakan mahasiswa S2 sudah bekerja sebagai guru. Karena profesinya itu menyebabkan mahasiswa sudah paham dan sering menggunakan instrumen-instrumen yang digunakan dalam penelitian terutama penelitian pendidikan. Sebagaiamana sebuah ungkapan bahwa experience is the best teacher. Dalam hal ini pengalaman menjadi guru membuat mahasiswa S2 lebih mahir dalam menentukan dan menggunakan instrumen-instrumen penelitian.

11) Penyusunan Teknik Analisis Data

Dari 42 orang mahasiswa, ada 39 orang (94\%) yang dinilai berhasil dalam menentukan teknik analisis data penelitiannya, dan dari 39 orang tersebut hanya 17 yang berasal dari jenjang S1, sisanya (22 orang) berasal dari mahasiswa 


\section{QUALITY}

Volume 5, Nomor 1, 2017: 83-103

jenjang S2. Dengan demikian mahasiswa S2 memiliki kemampuan lebih baik dalam menyusun teknik analisis datanya dibandingkan dengan mahasiswa S1. Hal ini bisa dikarenakan banyak faktor dianataranya faktor psikologis yaitu bahwa mahasiswa S2 merasa bahwa mereka harus memiliki self esteem yang tinggi dibanding mahasiswa jenjang S1. Self esteem yaitu keyakinan terhadap kemampuan mahasiswa S2 dalam menyusun laporan penelitian diantaranya dalam menyusun teknik analisis data. Tidak hanya itu, faktor pengalamanpun menjadi salah satu faktor mengapa mahasiswa S2 lebih baik dalam menyusun teknik analisis datanya daripada S1. Faktor pengalaman yang dimaksud adalah pengalaman mengenyam pendidikan tinggi. Bagaimanapun, mahasiswa S2 memiliki pengalaman akademik lebih banyak dibanding mahasiswa S1.

12) Penyusunan Hasil Penelitian

Dalam menyusun hasil penelitian, hal-hal yang perlu dilaporkan meliputi: hasil uji coba instrumen penelitian, pelaksanaan pengumpulan data, deskripsi subjek penelitian, uji prasyarat, uji hipotesis, dan pembahasan. Secara keseluruhan (96\%, 40 dari 42 orang) mahasiswa sebagai subjek penelitian telah membuat laporan penelitian secara sempurna. Poin-poin yang seharusnya dimunculkan dalam laporan penelitian telah dimunculkan semua, meskipun belum detail. Mahasiswa S2 membuat laporan penelitian lebih detail dibandingkan dengan mahasiswa S1 (10\%, 25 orang dari 40 orang).

13) Penyusunan Pembahasan

Pembahasan merupakan analisa peneliti terhadap hasil penelitian yang diperoleh. Peneliti perlu menjelaskan mengapa temuan penelitiannya demikian. Peneliti dapat menyampaikan argumen dari berbagai perspektif seperti agama, pendidikan, psikologi, antropologi, dan sebagainya.

Pada bagian ini mahasiswa nampak masih sangat kesulitan. Ini dapat dilihat dari laporan penelitian yang dibuatnya. Hanya 27\% (11 dari 42 orang) yang dapat menyusun pembahasan dengan baik. Sisanya (31 dari 42 orang, 73\%), masih dinilai buruk. Pada bagian ini kebanyakan mahasiswa hanya mengulangulang hasil yang sudah dilaporkan pada bagian penyusunan hasil (bagian sebelumnya), belum mengungkapkan mengapa alasan temuannya demikian. 


\section{QUALITY}

Volume 5, Nomor 1, 2017: 83-103

Padahal ini penting dan dapat menunjukkan apakah kajiannya mendalam atau tidak. Bahkan mahasiswa dapat memunculkan alasan dari berbagai perspektif sehingga dapat memperkaya temuan penelitian.

14) Penyusunan Daftar Pustaka

Meskipun bagian ini merupakan bagian yang bersifat teknis namun menjadi bagian yang tidak kalah penting. Di sini mahasiswa dapat menunjukkan apakah dia mempunyai kemampuan menulis yang baik atau tidak. Mahasiswa harus memahami perkembangan EYD (Ejaan Yang Dibenarkan). Namun dari hasil penelitian ini menunjukkan bahwa 22 dari 42 orang (51\%) masih banyak yang salah dalam penulisan daftar pustaka. Ada yang masih mencantumkan gelar dalam penulisan referensi, menggunakan kata belakang dan sebagian lagi menggunakan kata depan penulis, tidak disusun alpabetik, dan tata tulis yang salah ketika menggunakan sumber rujukan dari jurnal online. Ini menunjukkan bahwa mereka (mahasiswa jenjang S1 dan S2) belum memahami secara baik tentang tata cara penulisan daftar pustaka.

\section{5) Penataan Lampiran}

Hampir sama dengan penyusunan daftar pustaka, ini merupakan bagian teknis namun memberi arti yang sangat penting. Keruntutan dalam penyusunan lampiran akan membuat pembaca secara psikologis merasa nyaman dan mempermudah dalam memahami alur penelitian yang telah dilakukan.

Dari 42 orang yang menjadi subjek penelitian ini, 37 (89\%) di antaranya telah menyusun lampiran penelitian dengan baik. Ini terutama terjadi pada mahasiswa S1 (27 dari 37 orang). Ini menunjukkan bahwa mahasiswa S1 memiliki kepatuhan yang lebih tinggi dibanding mahasiswa S2 karena semua mahasiswa mendapat bimbingan yang sama termasuk bagaimana cara menata lampiran secara baik.

Dari seluruh hasil di atas, dapat dirangkum sebagaimana ditunjukkan pada Tabel 2. 
QUALITY

Volume 5, Nomor 1, 2017: 83-103

Tabel 2. Rangkuman Hasil Penelitian Berdasar Komponen-komponen

dalam Karya Ilmiah (Skripsi/Tesis) $(\mathbf{N}=42)$

\begin{tabular}{|c|l|c|c|c|c|}
\hline No & Aspek Penilaian & Rentang & Kategori & Jumlah & Persentase \\
\hline 1 & Judul Penelitian & $80-100$ & Istimewa & 41 & 98 \\
\hline 2 & $\begin{array}{l}\text { Latar belakang } \\
\text { masalah }\end{array}$ & $80-100$ & Istimewa & 25 & 60 \\
\hline 3 & Rumusan masalah & $80-100$ & Istimewa & 36 & 85 \\
\hline 4 & Tujuan penelitian & $80-100$ & Istimewa & 36 & 85 \\
\hline 5 & Manfaat penelitian & $80-100$ & Istimewa & 37 & 88 \\
\hline 6 & Kajian pustaka & $80-100$ & Istimewa & 42 & 100 \\
\hline 7 & Landasan teori & $80-100$ & Istimewa & 23 & 56 \\
\hline 8 & Variabel penelitian & $80-100$ & Istimewa & 26 & 63 \\
\hline 9 & Subjek penelitian & $80-100$ & Istimewa & 32 & 76 \\
\hline 10 & Instrumen Penelitian & $80-100$ & Istimewa & 36 & 85 \\
\hline 11 & Teknik analisis data & $80-100$ & Istimewa & 39 & 94 \\
\hline 12 & Hasil penelitian & $70-79$ & Baik & 40 & 96 \\
\hline 13 & Pembahasan & $70-79$ & Baik & 11 & 27 \\
\hline 14 & Daftar pustaka & $70-79$ & Baik & 22 & 51 \\
\hline 15 & Lampiran & $80-100$ & Istimewa & 37 & 89 \\
\hline
\end{tabular}

Berdasar Tabel 2, kebanyakan subjek mendapat predikat istimewa dalam setiap bagian skripsi/tesisnya sebagaimana mengacu pada pedoman penilaian. Atas hal di atas dapat dinyatakan bahwa kebanyakan subjek mendapat predikat istimewa untuk skripsi/tesisnya. Jika dilihat berdasar jenjangnya (S1 dan S2), diperoleh hasil sebagaimana ditunjukkan Tabel 3.

Tabel 3. Rangkuman Kategorisasi Karya Ilmiah Mahasiswa Berdasar Jenjang Pendidikan

\begin{tabular}{|c|c|c|c|c|}
\hline Jenis Karya Ilmiah & Rentang Nilai & Kategori & Jumlah & Presentase \\
\hline \multirow{5}{*}{} & $80-100$ & Istimewa & 22 & $82 \%$ \\
\cline { 2 - 5 } & $70-80$ & Baik & 3 & $18 \%$ \\
\cline { 2 - 5 } & $60-70$ & Cukup & - & 0 \\
\cline { 2 - 5 } & $50-60$ & Kurang & - & 0 \\
\hline \multirow{5}{*}{} & $80-100$ & Istimewa & 15 & $90 \%$ \\
\cline { 2 - 5 } & $70-80$ & Baik & 2 & $10 \%$ \\
\cline { 2 - 5 } & $60-70$ & Cukup & - & 0 \\
\cline { 2 - 5 } & $50-60$ & Kurang & - & 0 \\
\hline
\end{tabular}

Berdasar Tabel 3, baik skripsi ataupun tesis secara keseluruhan berada dalam kategori istimewa. Ini artinya bahwa mahasiswa S1 dan S2 mengalami peningkatan yang signifikan dalam hal kualitas karya ilmiahnya setelah menerapkan bimbingan regulasi diri dalam belajar. 
QUALITY

Volume 5, Nomor 1, 2017: 83-103

\section{Simpulan}

Berdasar uraian di atas dapat disimpulkan bahwa bimbingan regulasi diri dalam belajar efektif dalam meningkatkan kualitas karya ilmiah mahasiswa, yang dalam hal ini adalah skripsi dan tesis. Indikasi meningkatnya kualitas karya ilmiah dapat dilihat dari kategori karya ilmiah yang diperoleh mahasiswa tersebut yakni secara keseluruhan $(90 \%)$ berada dalam kategori istimewa dengan nilai merentang dari 80-100 (sesuai acuan penilaian skripsi/tesis).

\section{DAFTAR PUSTAKA}

Alsa, A. (2005). Program Belajar, Jenis Kelamin, Belajar Berdasar Regulasi Diri, dan Prestasi Belajar Matematika pada Pelajar SMA Negeri di Yogyakarta. Disertasi (tidak diterbitkan). Yogyakarta: Program Pascasarjana UGM.

Anonim. (T.th). Pengertian Karya dan Jenis Karya Tulis Ilmiah. [Online]. Tersedia: $\quad$ http://pengertiandefinisi.com/pengertian-karya-ilmiah-dan-jenisjenis-karya-ilmiah/. Diunduh tanggal 16 Pebruari 2015, Pukul 09:25 WIB.

Arikunto, S. (2009). Manajemen Penelitian. Jakarta: Rineka Cipta.

(2009). Prosedur Penelitian Suatu Pendekatan Praktek. Jakarta: Rineka Cipta.

Azwar, S. (1996). Tes Prestasi. Yogyakarta: Pustaka Pelajar. . (2012). Penyusunan Skala Psikologi Edisi 2. Yogyakarta: Pustaka Pelajar.

Bandura, A. (1977). Social learning Theory. Englewood Cliffs, NJ: Prentice-Hall.

Biantoro, A. W. (2009). Perbedaan Skripsi dan Tesis. [Online]. Tersedia: https://uripsantoso.wordpress.com/2012/04/12/perbedaan-skripsi-tesis-dandisertasi-secara-sederhana/. Diunduh tanggal 16 Pebruari 2015, Pukul 09:25 WIB.

Imam, G. (2008). Model Persamaan Struktural-Konsep dan Aplikasi dengan Program AMOS 16.0. Semarang: BP Universitas Diponegoro.

Latipah, E. (2010). Strategi Self Regulated Learning dan Prestasi Belajar: Kajian meta analisis. Jurnal Psikologi UGM, 1 (37)110-128. (2012). Pengantar Psikologi Pendidikan. Yogyakarta: Pedagogia. 


\section{QUALITY}

Volume 5, Nomor 1, 2017: 83-103

Deepublish.

(2014). Metode Penelitian Psikologi Pendidikan. Yogyakarta:

(2015). Hasil wawancara terhadap sejumlah mahasiswa tentang kebiasaan belajar mereka dalam rangka pre liminary penelitian. Wawancara dilakukan pada tanggal 18 Oktober 2015.

Maehr, M. L. \& Meyer, E. M. (2004). Reinventing schools early adolescents: Empashizing task goals. The Elementary School Journal, 93, 593-610.

Moeloeng, L. J. (1996). Metodologi Penelitian Kualitatif. Bandung: Remaja Rosdakarya.

Ormrod, Jeanne. E. (2008). Educational Psychology Developing Learners Jilid 1 $\left(6^{\text {th }} e d\right)$. New Jersey: Prentice-Hall, Inc.

Passer, M. W. \& Smith, R. E. (2009). Psychology The Science of Mind and Behavior. Toronto: McGraw Hill International Edition.

Pekrun, R., Goetz, T., Titz, W., Perry, Raymond, P. (2002). Academic Emotions in Students' Self-Regulated Learning and Achievement: A Program of Qualitative and Quantitative Research. Educational Psychologyst, 37 (2): 91105).

Saddler, B. (2006). Increasing story writing ability through self regulated strategy development: effect on young writers with learning diasabilities. Innovative Higher Education, 29 (1), 291-305.

Schapiro, Susan, R. and Livingston, Jennifer, A. (2010). Dynamic SelfRegulation: The Driving Force Behind Academic Achievement. Innovative Higher Education. 25 (1), 23-35).

Slavin, R. E. (2009). Educational Psychology. Engleewood Cliffs, New Jersey: Prentice-Hall, Inc.

Sunawan. (2003). Pengelolaan Diri dalam Belajar untuk Meningkatkan Prestasi Belajar Matematika Pada Siswa Sekolah Mennegah Umum (SMU). Tesis (tidak diterbitkan). Yogyakarta: Program Pascasarjana UGM.

Winne, P. H. (1995). Inherent Details in Self Regulated Learning. Educational Psychologist, 30, 173-188.

Winne, P. H., \& Hadwin, A. F. (2008). Studying as self regulated learning. Dalam D. J. Hacker, J. Dunlosky, \& A. C. Graesser (Eds). Handbook of Self Regulation (p. 531-566). Orlando, FL: Academic Press. 
QUALITY

Volume 5, Nomor 1, 2017: 83-103

Woolfolk, A. (2008). Educational Psychology Active Learning Edition-Tenth Edition. Boston: Allyn \& Bacon.

Zimmerman, B. J. \& Martinez-Pons, M. (1998). Construct Validation of Strategy Model of Student Self Regulated Learning. Journal of Educational Psychology, 80 (2), 284-290

Zimmerman, B. J. (1986). Becoming a Self-Regulated Learner. Which are the key subprocesses? Contemporary Educational Psychology, 11, 307-313.

Zimmerman, B. J. (2004). Becoming a Self Regulated Learner: An Overview. Theory into Practice, 41, 64-70. 